\title{
Urban Farming Management System In Semarang City
}

\author{
Lutfiyatul Wahdah ${ }^{1, *}$ and Maryono Maryono ${ }^{2}$ \\ ${ }^{1}$ Magister Program of Environmental Science, School of Postgraduate Studies, Diponegoro University, Semarang - Indonesia \\ ${ }^{2}$ Department of Urban and Regional Planning, Faculty of Engineering, Diponegoro University, Semarang - Indonesia
}

\begin{abstract}
Urban farming is one of the new cultivation methods in the urban area. It becomes one of Semarang City government's efforts to fulfil urban society food needs. The background of the urban farming concept is the limitations of land in agriculture production by people living in the urban area. Urban farming in Semarang City consists of hydroponic and aquaponic. Hydroponic cultivation is easier to do because of the nutrients needed measurably derived from artificial nutrients (non-chemical). While in aquaponic have two elements, they are aquaculture and vegetables grown. Both of these urban farming concepts have the principle of planting media with no use of land and are appropriately implemented in urban areas. The purpose of this research is to know how urban farming management system in Semarang City. The research method used is quantitative descriptive and conducted in Semarang City. The primary data were collected by questionnaires and field observations, while the secondary data came from the literature study and previous research. From the result of this research recommend the application of urban farming technology that prioritizes environmental protection with social and economic aspects.
\end{abstract}

Keywords : urban areas; limitation of land; urban farming

\section{Introduction}

The urban population increasing trend annually due to uncontrolled population growth and uncontrolled urbanization. The increasing of population and urbanization number causes the increase land use change from open space to be a built-up area. This land use change commonly converts agricultural land into industrial land, commercial, and settlement. The changing in agricultural land function basically occur due to competition in land use between agricultural and non-agricultural sectors. Competition in land use utilization appears due to economic and social phenomena (limited land resources, population growth, and economic growth) [1].

Urban agriculture is one of currently phenomena in utilizing the limitations of land in urban areas. This urban agriculture activity aims to mobilize urban communities with the minimum possible land to keep agricultural cultivation activities. Urban agriculture is not only in horticultural crops dimensions but also in livestock activities. Urban agriculture is agricultural activity in or around the city that involves skills, expertise, and innovation in food processing cultivation for the community through the use of yard, empty land to increase nutrition, improve the economy and family welfare [2]. Based on a set of agricultural activities in urban areas, so the purpose of applying the concept of urban agriculture is to provide food supply in urban areas.
Supporters of urban agriculture expressed some benefits to urban agriculture, they are: (1) reduce unproductive urban land under management with local government; (2) improve the public image of the problematic environment: (3) increasing the number of green space areas; (4) supply low-income populations with health and more nutrition; (5) developing selfsufficiency among residents in the city who grow food for themselves and others; (6) revitalization of the poorest environment by creating food-based employment(especially for young people), thus bringing more income to the community; (7) providing new nontraditional program activities for non-profit based community organizations; (8) convert food waste from supermarkets into compost and fertilizer used in food production; (9) reduce food transportation through greater availability of local products; and (10) support local and regional food systems in general [3].

Urban farming forms include small farms and farmsintensive, residential food production, land sharing, rooftop gardens, greenhouses in schools, restaurants integrated with gardens, food production in the public space, and vegetable production in the vertical space [4]. The concept of urban farming developed in the Semarang City settlement consists of hydroponic and aquaponics. The applying urban agriculture concept with media without using the land and is very suitable applied in this city.

Urban farming currently is a trend in urban communities and emerging communities trying to

* Corresponding author: lutfiyatulwahdah@gmail.com 
practice urban farming. In Semarang, the urban farming movement is built on the communities idea and innovation to become a new method of cultivation in urban areas. Based on Urban Farming Activity Profile of Semarang data, there are Urban 98 entrepreneurs Farming entrepreneurs in Semarang. It is consist of 80 aquaponics entrepreneurs and 18 hydroponics entrepreneurs. These entrepreneurs locations were scattered and located in various areas in Semarang. The urban farming program is conducted by some communities in the central area of Semarang were interested in organic vegetable planting but can not develop it because of the limited land they have.

Based on the explanation above, this research aims to identify the urban farming management system in Semarang. They are what is the product produced, water source and energy used, and the ability of society in urban farming management.

\section{Research Method}

The research method used in this research is the quantitative descriptive method, that is a method of analysis which is presented systematically, used to research on a certain sample or population, data analysis is numerical (quantitative), with the purpose to test a hypothesis which has been determined. Sampling technique in this research using simple random sampling and purposive sampling method [5]. It is simple random sampling because sampling from the population is taken randomly without considering the strata in the population [5]. The entire population has the same opportunity to be sampled.

The sample is the urban community of Semarang City which has urban farming business. The number of respondents in this study are 59 respondents, with the composition of 44 respondents aquaponics business and 15 respondents of hydroponic business actors. The data collection method used is a primary survey with the direct observation on urban agriculture area. Secondary data collection methods are obtained from the literature, institutional survey and documentation printed in the form of written records of various events or events in the past or have occurred. The data is statistical data that have been published by BPS periodically, related research literature, and all documents from agencies.

The scoring method in this study used to assess the effectiveness of urban farming management in Semarang. It use several measurement criteria and a number of scores will be obtained from the respondent's answers. From each of these assessments, will be obtained by adding up all the scores of each variable indicator. The results of this assessment will distinguish between ineffective, less effective and effective. The results of the assessment produced the highest score and the lowest score. From the results of this assessment, the assessment results are then interpreted to determine the range of assessment intervals. The range of effectiveness values used in assessing the effectiveness of urban farming management is shown in the Table 1 below:
Table 1. Effectiveness Value of Urban Farming Management

\begin{tabular}{|c|c|}
\hline Score Percentage & Category \\
\hline $0 \%-33,33 \%$ & Ineffective \\
\hline $33,34 \%-66,67 \%$ & Less effective \\
\hline $66,67 \%-100 \%$ & Effective \\
\hline
\end{tabular}

\section{Result and Discussion}

\subsection{Implementation of Urban Farming}

Urban farming is one of the new farming method in urban areas and it is a manifestation of Semarang City government efforts to fulfill the urban community needs in food. The application of the urban farming concept is motivated by people living in urban areas who have limited land in producing agricultural products. In addition to utilizing limited land, the concept of urban farming also utilizes lands that were not productive to productive land so as to improve environmental quality; increasing green land in the city area; improve environmental aesthetics and image; and providing opportunities for low-income households to be able to consume good quality food products and contain high nutritional value, at affordable prices [3]. The fulfillment of food from the results of farming alone can improve welfare because the allocation of money that was previously used to buy food can now be provided on its own.

The real practice in applying urban farming in the neighborhood of Semarang City is to apply the concepts of hydroponics and aquaponics. Hydroponic cultivation is easier to do because of the nutrients needed measurably derived from artificial nutrients (nonchemical). Hydroponics is the cultivation of planting by using water without using soil with emphasis on the fulfillment of nutritional needs for plants. The water needs on hydroponics is less than the water needs for cultivation with soil. Hydroponics use water more efficiently, so it is suitable to apply in limited water supply areas. While in Aquaponic have two elements, they are aquaculture and vegetables grown. The aquaponic technology combines the cultivation of fish and vegetables with recirculation system as a simple but effective technology. This technology prioritizes the efficiency of land and utilization of fish organic waste as fertilizer for plants that are above it. The development of this technology can produce multiple products in one production cycle. Furthermore, this technology able to increase the independence and productivity of the community so indirectly expected to support the economy and welfare community in Semarang. 

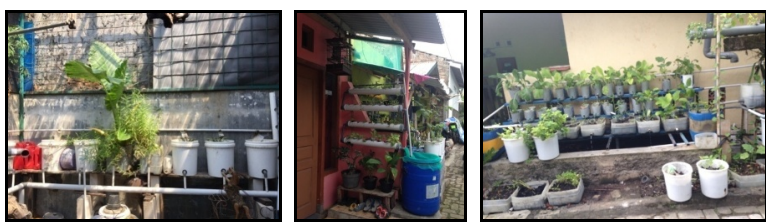

Fig. 1. Aquaponics in Semarang

Although the implementation of urban farming is easier to do with the concept of hydroponics, people who do hydroponic less than aquaponics. It caused aquaponics agriculture can produce two commodities at once, there are additional crops other than vegetables, the fish itself. Based on data derived from the Urban Farming Activity Profile of Semarang, the total number of Urban Farming in Semarang City is 98 entrepreneurs consisting of 80 Aquaponics entrepreneurs and 18 Hydroponic entrepreneurs. For its distribution, there are differences in the distribution of aquaponic and hydroponic farming locations in Semarang. Communities that develop aquaponic farming systems tend to cluster in an area, it is Kandri Village, Gunungpati District. While others are located in Kalipancur Village, Ngaliyan District and Jatisari Village, BSB. While hydroponics are all spread in various regions in Semarang.
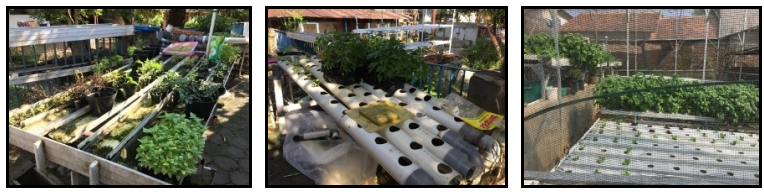

Fig. 2. Hidroponics in Semarang

\subsection{Urban Farming Management}

\subsubsection{Location of urban farming}

Urban farming is an agricultural activity that does not require extensive land. All urban farming activities in Semarang whether conducted aquaponic or hydroponic, only utilize the house terrace. This activity can maximize the production obtained even though it is doing on narrow land.

\subsubsection{Energy Source (water and electricity)}

Water and electricity are the main energy sources used in hydroponic and aquaponic agriculture. The city of Semarang has good and adequate conditions for clean water and electricity. The water used for hydroponic and aquaponic farming needs in Semarang City comes from relatively cleaner PDAMs with a lower level of pollution compared to irrigation water in conventional agriculture. While electricity is used as energy to drain water to plants. This condition causes the products produced from hydroponics and aquaponics to grow relatively clean and hygienic than conventional agricultural products.

In addition to saving water and saving land hydroponic and aquaponic farming methods are also very energy efficient. The energy referred to in this case is energy derived from petroleum, usually used to plow the land or in other plant maintenance businesses. In this system only uses $25 \%$ of the total energy used in conventional planting methods and the overall energy used in hydroponic and aquaponic methods is derived from electrical energy that can be obtained from more environmentally friendly sources.

\subsubsection{Nutrition}

Aquaponics and hydroponics have different planting processes. The fundamental difference is the nutrients used as fertilizer. Aquaponics uses nutrients from fish feces which are also cultivated. While hydroponics uses additional nutrients. So that aquaponics has additional planting media, namely fish ponds for planting vegetables on it.

Hydroponic agriculture uses measurable additional nutrients added to water in the hydroponic system. These nutrients are placed in a container and then channeled directly to the roots of the plant so that the plant is easier to absorb the nutrients. The amount of nutrition in hydroponics needs to be carefully regulated because if lack of nutrients, the plants will not grow well while if too much nutrients will cause the plants to be poisoned by nutrition will not be able to absorb properly and eventually the plants die soon. The measured nutrients make results Hydroponic planting has become more stable and well developed so that the hydroponic sales scale is relatively broad to be a supplier of several Super markets, Hotels and Cafes in Semarang City. Unlike hydroponics, the aquaponics system no longer needs to provide nutrient solutions to plants because nutrients have been met by organic matter from fish feces and urine. These nutrients are not measurable because they depend on the pattern of care and planting of the business actor in balancing their fish and aquaponics. .

\subsection{Sales or Utilization of Urban Farming}

The urban farming program is one of the solutions in increasing agricultural production. The benefits that can be felt by the citizens of Semarang City with this urban farming program is to provide food for the consumption of family members. With the fulfillment of foodstuffs from the results of farming alone can improve welfare because the allocation of money that was previously used to buy food can now be provided by itself. The next benefit is to be able to increase family income if the agricultural produce can be sold.

For aquaponic farming, the majority of agricultural products are for personal consumption. This can be seen from the results of the questionnaire which illustrates $86 \%$ of respondents gave a statement that their agricultural products have not been sold to outsiders. This is because aquaponics agricultural products are more used to meet family food needs. Whereas $14 \%$ of the other respondents stated that their aquaponics agricultural products were sold but the sales were only to nearby neighbors. 
Aquaponics and hydroponic agricultural products have different sales scales. The difference can be seen from the results of a questionnaire that illustrates $60 \%$ of respondents from hydroponic farming have sold their agricultural produce, $13 \%$ of respondents said their hydroponic agricultural products have not been sold, and $27 \%$ of respondents stated for personal consumption . The description of the sale of urban farming results is shown in the picture below.

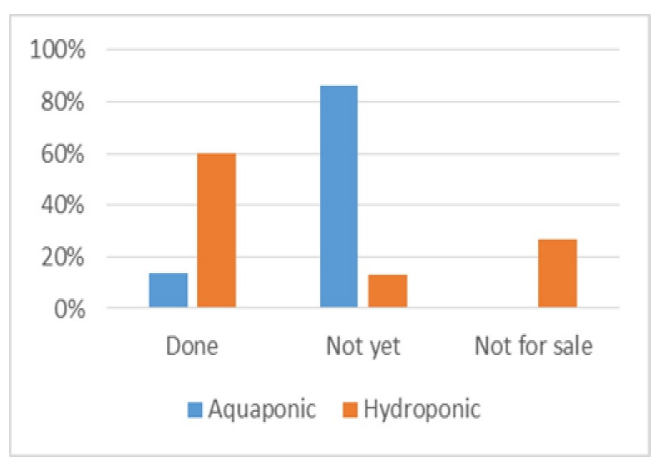

Fig. 3. Sales of urban farming

The main objective of urban farming is to meet the family's food needs. Semarang City residents who do urban farming activities in their homes are not burdened by production targets that must be achieved, because the orientation is not to gain financial benefits. The results of the study show that only hydroponic agriculture has succeeded in selling agricultural products not only to neighboring areas. As many as $55 \%$ of respondents have managed to sell directly to traditional markets, $27 \%$ of respondents sell their agricultural products to supermarkets, hotels, markets, and the hydroponic community itself. The rest is sold to neighbors (18\% of respondents). For that reason, urban farming has become a promising home-based business because it can improve the family's economy and even become their main livelihood.

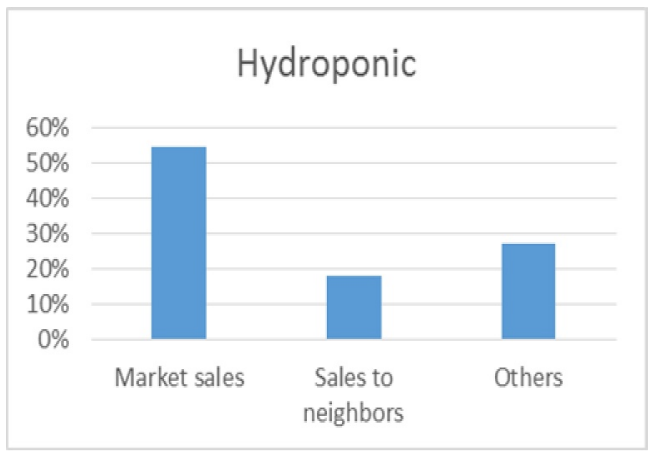

Fig. 4. Sales Process

\subsection{Effectiveness of Urban Farming Management in Semarang's Settlement Environment}

Analysis of the effectiveness of managing urban farming in Semarang City is seen from several criteria, namely the success of the program, the fulfillment of food needs, the role of urban farming in the supply of food, sales of products, and satisfaction with the program. Based on the results of the questionnaire with the calculation of the percentage score interpretation criteria, it is known that respondents who rated the success rate of urban farming programs developed in the neighborhood of Semarang City had reached a score of $87.01 \%$. This condition is influenced by the ability of people who are successful in utilizing limited land, so as to be able to move the urban community with a minimum of land to be able to continue farming activities. The effectiveness of the program's success is an effort to assess the level of achievement of objectives in organizing urban farming activities in a residential neighborhood. General effectiveness aims to find out the changes caused before and after the program is run so that it can be known how far the needs, values, and opportunities have been achieved [6].

Another criterion used to review the effectiveness of managing urban farming in Semarang City is the fulfillment of food needs. Judging from the fulfillment of food needs, the score obtained was $65.54 \%$ with the category of less effective. This means that the urban farming program that is implemented has not been able to help the family's food needs as a whole and most of the respondents still buy vegetables or fish in the market. This condition also affects the role of urban farming in the supply of family food. Based on the results of the scoring analysis, it was found that the effectiveness of urban farming in providing family food needs had a score of $68.36 \%$. This percentage is considered effective because the results of urban farming production can be obtained at any time or during the harvest season.

Urban farming programs are a new trend in carrying out agricultural activities in urban areas. This program also affects city residents in improving welfare because the allocation of money that was previously used to buy food can now be provided on its own. The next benefit is to be able to increase family income if the agricultural produce can be sold. This can be seen from the results of the scoring which shows that the results of urban farming production are effective in improving welfare, with a score of $77.40 \%$. These conditions affect the level of respondents' satisfaction with urban farming activities that have been carried out, with a score of $80.79 \%$.

Based on the scoring calculations that have been done to analyze the effectiveness of urban farming management in Semarang City, it can be concluded that the ranking of the effectiveness of urban farming management is seen in the following table:

Table 2. Effectiveness of Urban Farming Management in Semarang

\begin{tabular}{|c|c|c|c|c|}
\hline 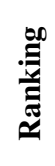 & 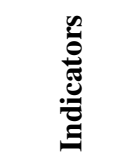 & 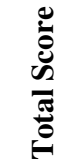 & & 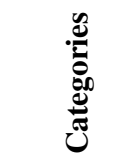 \\
\hline 1 & $\begin{array}{c}\text { Program } \\
\text { success }\end{array}$ & 154 & $87,01 \%$ & Effective \\
\hline
\end{tabular}




\begin{tabular}{|c|c|c|c|c|}
\hline 2 & $\begin{array}{c}\text { Level of } \\
\text { satisfaction } \\
\text { with the } \\
\text { program }\end{array}$ & 143 & $80,79 \%$ & Effective \\
\hline 3 & $\begin{array}{c}\text { Sales of } \\
\text { products }\end{array}$ & 137 & $77,40 \%$ & Effective \\
\hline 5 & $\begin{array}{c}\text { The role of } \\
\text { urban farming } \\
\text { in the } \\
\text { provision of } \\
\text { food needs }\end{array}$ & 121 & $68,36 \%$ & Effective \\
\hline 5 & $\begin{array}{c}\text { Fulfillment of } \\
\text { food needs }\end{array}$ & 116 & $65,54 \%$ & $\begin{array}{c}\text { Effective } \\
\text { Enough }\end{array}$ \\
\hline
\end{tabular}

Scoring results in the table above show that the indicator that has the highest level of effectiveness in managing urban farming is the success of the program with a score of $154(87.01 \%)$. While the indicator that has the lowest level of effectiveness is the fulfillment of food needs with a score of $116(65.54 \%)$ which is included in the category of quite effective. The urban farming program is categorized as effective in dealing with urban problems because it can bring several benefits. These advantages can be grouped into three aspects, namely: social, economic and environmental aspects [7].

- Social aspects: open new jobs so as to reduce unemployment; increase food availability; as an alternative source of affordable food in meeting the needs of food so as to improve nutrition and public health.

- Economic aspects: opening business opportunities because in addition to family consumption, urban farming products can also be sold; increase people's income; reducing poverty.

- Environmental Aspects; limited land use; improved air quality; adding aesthetics; increase food production locally.

\section{Conclusion}

This study aims to determine the management system of urban farming in the city of Semarang. The following are the results obtained in this study:

1. Implementation of Urban Farming

The application of the urban farming concept is motivated by urban communities who have limited land in producing agricultural products. A real example in the application of urban farming in the neighborhood of Semarang City is by applying the concepts of hydroponics and aquaponics. Communities that do less hydroponic farming than aquaponic farming. This is because aquaponics agriculture can produce two commodities at once, namely there are additional crops besides vegetables, namely the fish itself.

2. Urban Farming Management

- Urban farming is an agricultural activity that does not require a large area of land, either aquaponically or hydroponically can use the terrace of the house for agricultural activities.
- Water and electricity are the main energy sources used in urban farming.

- Nutrients used in aquaponic and hydroponic agriculture have significant differences. Aquaponics use nutrients from fish feces or fish feed residues

3. Most urban farming products are still used for personal consumption. This is because urban farming that is developed is still limited to the home page.Based on the results of the scoring analysis shows that the indicator that has the highest level of effectiveness in managing urban farming is the success of the program with a score of 154 (87.01\%). While the indicator that has the lowest level of effectiveness is the fulfillment of food needs with a score of $116(65.54 \%)$ which is included in the category of quite effective.

4. In addition to utilizing limited land, urban farming also utilizes lands that were previously unproductive to become productive land so as to improve the quality of the environment; increasing green land in the city area; improve aesthetics and environmental image. The fulfillment of food from the results of farming alone can improve welfare because the allocation of money that was previously used to buy food can now be provided on its own. Another benefit felt by urban farming activists in the neighborhood of Semarang City is to contribute to saving the environment through the management of 3R (reuse, reduse, recycle), can produce oxygen to improve the quality of the city's environment, and reduce air pollution.

\section{Acknowledgment}

This research is funded by the Directorate of Research and Community Services, Ministry of Research, Technology and Higher Education for year 2018 with contract number 101-147/UN7.P4.3/PP/2018. This research also funded by annual program of strategic research of Faculty Engineering, Diponegoro University year 2018 with contract number 267/UN.3.3/PG/2018

\section{References}

[1] Sampeliling, S., Sitorus, SRP., Nurisyah, S., Pramudya, B. Kebijakan Pengembangan Pertanian Kota Berkelanjutan: Studi Kasus di DKI Jakarta. Jurnal Analisis Kebijakan Pertanian, Volume 10 Nomor 3, 257 - 267. 2012.

[2] Wiyanti, AN. Implementasi Program Urban Farming Pada Kelompok Sumber Trisno Alami Di Kecamatan Bulak Kota Surabaya. Jurnal Publika, Volume 1 Nomor 2, 1 - 15. 2013.

[3] Kaufman, Jerry dan Martin Bailkey. Farming Inside Cities: Entrepreneurial Urban Agriculture in the United States. Madison: Lincoln Institue. 2000 . 
[4] Fauzi, AR., AN. Ichniarsyah, dan H. Agustin. Pertanian Perkotaan: Urgensi, Peranan, dan Praktik Terbaik. Jurnal Agroteknologi, Volume 10 Nomor 1, 49 - 62. 2016.

[5] Sugiyono. Metode Penelitian Kuantitatif, Kualitatif dan R \& D. Bandung: CV. Alfabeta. 2008.
[6] Dunn, N. William. Pengantar Analisis Kebijakan Publik. Jakarta: Gadjah Mada University Press. 1998.

[7] Mazeereuw. Urban Agriculture Report. Region Waterloo. Public Healt. 2005. 